Vol. 2, No. 1, 2021

\author{
Vsevolod Prykhodko', Ihor Vikovych ${ }^{2}$ \\ 1. MG Logistics Inc \\ 10505, Delta Pkwy, Schiller Park, IL 60176, USA \\ 2. Lviv Polytechnic National University \\ 12, Bandery Str., Lviv, 79000, Ukraine \\ (C) Prykhodko V., Vikovych I., 2021 \\ https://doi.org/ 10.23939/tt2021.01.050
}

\title{
ANALYSIS OF CALCULATING LEVEL OF SERVICE FOR PEDESTRIANS
}

\begin{abstract}
Summary. In this paper, several methods of the assessment of pedestrian objects operation based on the level of service are reviewed. Today, there is a problem that should be assessed, particularly how pedestrian paths respond the level of service. Assessment of this level is the most widespread method of determination the objects `quality that relate to the pedestrian operations. Places, where a significant probability of conflict between different flows and their users, are often called intersections. Moreover, on such intersections, particularly with complex road conditions and on which the movement of cyclists, cars, and different vehicles is present, road users face with complicated situations when every of them should be sure in his safety and forecast further actions and decisions of other road users. The most widespread and generally accepted methods of assessment of level of service on pedestrian path, particularly: Highway capacity manual 2000 method, Australian method, method of the trip quality, Landice model and common approach analysis. Vehicles, signal delay, and interaction of pedestrians and cyclists were determined as the main factors that have impact on the level of service of pedestrians at the intersections. Analysis of different methods in the paper allows assessing and identifying the level of service determining the characteristics that could help in solving the questions concerning the comfort of pedestrian movement. In the range of these methods, the principles of vehicles movement and interaction with pedestrians are also reviewed. Other methods relate more to the design of the objects of pedestrian environment than factual movement of pedestrians. To form the whole understanding of the methodology of determination of the level of service of pedestrian objects, we should analyze and compare the values, obtained by different methods.
\end{abstract} sidewalk.

Key words: pedestrian, pedestrian facilities, heavily trafficked intersections, pedestrian

\section{INTRODUCTION}

Since the pedestrian environment is multi-dimensional, many factors influence the behaviour of a pedestrian in the roadside environment, his awareness of safety, and ease of movement. The analysis of these factors is extremely important for the assessment of pedestrian objects, and assessment methods provide an understanding of how much a particular street is suitable for pedestrians.

Designing adequate walk-in environments requires methods by which planners and decision-makers can effectively identify and evaluate the elements of the built surroundings that support or detract from walking. Over the years, the quality of the pedestrian environment has undergone changes using the level of service approach. LOS is influenced by many factors, and different pedestrians have different perceptions of LOS. 
Since the late nineties, more and more emphasis has been placed on cycling and walking to address congestion, air and life quality [1]. A survey, conducted in the United States, released on April 1, 2003, that was commissioned by the Surface Transportation Policy Project shows that many Americans are in favour of walking as a transportation mode of choice. The poll found that 55 percent of the adults would rather walk than drive if given the choice [2].

In recent years, Pedestrian accessibility concepts have gained widespread acceptance in the United States, educating people about the benefits of walking and deepening cooperation with municipal authorities to improve facilities that serve non-motorized traffic. In this regard, it is extremely important to assess the performance of pedestrian facilities to determine the quality of operation, identify problems, and further improve them.

By implementing the concept of level of service, it is possible to assess the performance of vehicles. More specifically, the Highway Capacity Manual 2000 (HCM 2000) offers level of service criteria for uninterrupted flow pedestrian facilities based on measures similar to those used for motorized LOS, i.e., on the basis of the flow-speed-density relationship [3]. The threshold to determine the six levels of service criteria is based on the space available to each pedestrian and speed. However, the multi-faceted aspects involved in pedestrian movements can be more complicated than the movements of other modes. Some of the factors related to the pedestrian quality of service can be qualitative rather than quantitative and are often difficult to measure. Determining the LOS of pedestrian facilities can be a complex but important process.

Critics suggest that current pedestrian LOS methodologies are modelled too closely after vehicular LOS, often resulting in inadequate and contradictory assessments, or even showing good LOS values in an in-hospitable walking environment [4]. A basic question remains as to whether the HCM 2000 addresses pedestrian quality of service based on the user's perception [5].

Many researchers argue that an effective pedestrian LOS method should consider both the operating conditions of a system and how the users perceive such conditions [6]. To better understand the factors that determine the quality of the operation of pedestrian objects and how they may be incorporated in a LOS methodology, this paper reviews and compares several proposed assessment methods for pedestrian sidewalks in urban conditions. These include the Highway Capacity Manual 2000 method, the Australian method, the Trip Quality Method, the Landis model, and the Conjoint Analysis approach. The paper is an extension of some earlier studies by Cepolina, E. M., Menichini, F., and Rojas, P. G that used LOS-based methods for assessing the quality of operations at a university campus environment [7]. All methods considered are based on the LOS concept but involve different factors and assessment criteria. In each, a LOS of A represents the best quality of operations a facility can achieve, with LOS F the worst.

\section{ANALYSIS OF PREVIOUS STUDIES AND PUBLICATIONS}

Dixon (1996) proposed a pedestrian LOS evaluation criterion which involves the provision of basic facilities, conflicts, amenities, motor vehicle LOS, maintenance, and travel demand management, and multimodal provisions. There was no environmental evaluation in qualitative concern relating to walkability. This seems to be best suited to footpaths assessments; applicability to intersections was uncertain.

A mathematical model was proposed by Landis et al., (2001) based on five variables: lateral separation of pedestrians from motor vehicle traffic, presence of physical barriers and buffers, outside lane traffic volume, vehicle speed, and vehicle mix. Although the mathematical model analyses a road segment, it does not consider intersections. However, the conditions of the intersection have a great influence on the movement of pedestrians. Therefore, it is extremely important to modify the scoring mechanism to include conditions at intersections [8].

Gallin (2001) developed a simple model for determining how well paths and roads relate to the needs of pedestrians. The process involved the formulation of a method for assigning a LOS grade to pedestrian facilities that were based on the interpretation of factors affecting pedestrian LOS and the degree to which these factors are provided (or absent) on selected path segments [9]. 
Muraleetharan (2004) used a general technique to collect pedestrians affecting LOS. The main benefit is from the overall analytical value, which implies the share of the user contribution to the product and service. Even though during this study a method was developed to determine the total LOS, it does not contain all the factors affecting the pedestrian LOS.

Muraleetharan (2005) identified factors that influence the level of pedestrian service at intersections and formulated a method for assessing LOS for pedestrians at intersections. Based on this study, it was found that the vehicle turning factor is of greater importance for the pedestrian's LOS than other parameters. Also, signal delay parameters and pedestrian-bike interaction have also become key determinants of pedestrian LOS at intersections [8].

Statistical analysis using the binary logit model was developed by Hubbard (2009). This has formed a new understanding of the parameters that affect the likelihood that a pedestrian will be compromised, delayed, change his path or speed in response to a right turn. The implementation of the binary logit model of pedestrian compromise provides information that the probability of a pedestrian being compromised increases with an increase in the flow rate of vehicles when turning right [10].

According to a literature review, most of the work on pedestrians is limited to pedestrian objects on continuous sidewalks. On the other hand, there are several surveys on pedestrian issues at intersections. This specifies that an authentic measure is needed to define the pedestrian surroundings at intersections. Enlargement of pedestrian LOS measure for intersection is consequently intended to specify the level of complexity in crossing intersections.

\section{PROBLEM STATEMENT}

Pedestrians constitute the largest group of road network users and are also the most vulnerable road users. The pedestrian movement is not limited to lanes as it is in the road transport or specific routes, but limited only by the physical constraints around them, namely the presence of sidewalks or hiking trails. Therefore, pedestrian needs must be taken into account when designing a transport infrastructure. To know how the state of the road network provides a comfortable and safe pedestrian movement, there is a need to assess the conditions of pedestrian traffic and identify the main factors having a negative impact on the participants of the movement with the subsequent resolution of existing problems.

\section{MAIN MATERIAL PRESENTATION}

Comfort is a positive emotional reaction to the external environment or situation. The comfort of pedestrian traffic conditions can be considered as a certain emotional reaction to the external environment in different situations.

In engineering rapports, pedestrian overcrowding is recognized when a facility is operating over capacity. Capacity refers to the maximum possible ability to accommodate a flow [5]

The capacity of $75 \mathrm{ped} / \mathrm{min} / \mathrm{m}$ is shown in the Highway Capacity Guidelines [6]. The area required for one pedestrian when the sidewalk is full is $0.75 \mathrm{~m} 2$. Besides, this number indicates a high likelihood of conflict between pedestrians. In this regard, it is undesirable to operate at maximum capacity.

In real conditions and this study, the concept of pedestrian congestion is used to indicate moments with intense pedestrian flows. During these moments, pedestrians cannot walk at their pace. Congestion flow parameters: need to change trajectory and speed to avoid conflict, shuffle, evasion, stop and start conditions [11].

As a rule, improving the quality of pedestrian flow is not the main policy objective, which appears as such in the strategies of the city council. Nonetheless, favourable flow conditions are the basis for highly collaborative tasks such as promoting walking, improving the walking environment, emphasizing the role of walking as part of public transport travel, and stimulating public transport.

Many mechanisms contribute to the improvement of pedestrian flow during periods of congestion. In this analysis, pedestrian space management and pedestrian traffic management measures play an important role [12]. 
The assessment of pedestrian traffic according to HCM is determined by the LOS level for sidewalks based on the results of calculating pedestrian velocity, available personal space, and pedestrian flow intensity on the effective width of the sidewalk. That is, this method considers the pedestrian flow in the same way as the traffic flow, determining speed, density, and intensity. Conditions are considered comfortable for movement when the pedestrian has a sufficiently individual space to choose the desired path and speed [13].

\subsection{Impact of the schemes on the LOS}

A qualitative analysis was carried out of the likely impact of the schemes on the physical service layer in order to detect conflicts between pedestrians. It should be noted that one third of the conflicts could not be neglected by any of the schemes. At the same time, directional stripes can brighten up about 25 percent of conflicts, on the other hand, splitting streams by speed can reduce conflicts by $20 \%$. Moving and substituting road objects related to the flow: signs, markings, lighting equipment etc. have a small $17 \%$ opportunity, but without considering its possible results (Fig. 1). Replacement of road markings and signs has the obvious potential to free up space and therefore increase the width of the sidewalk. Location 1 will be analyzed as an example: the average effective pavement width during the day will increase from $3.55 \mathrm{~m}$ to $4.44 \mathrm{~m}$. $[14,15]$.

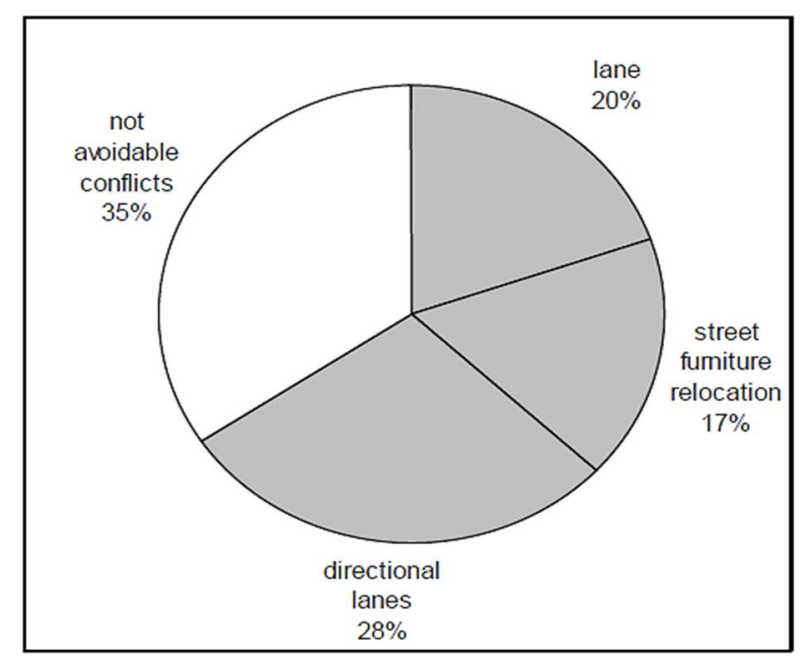

Fig. 1. Potential of each of the schemes to avoid conflicts

The P-LOS model consisted of a dependent variable and seven independent variables. The dependent variable was the P-LOS Score obtained through interviews and questionnaires. Pedestrians were asked to rate the crosswalks in terms of safety and comfort. The average rating of the pedestrians for each crosswalk is mentioned. Pedestrian flow (ped/hr), pedestrian crossing time (sec), pedestrian delay (sec), crosswalk surface condition ( 0 - poor, 1 - moderate, 2 - good), crosswalk marking ( 0 - not visible, 1 slightly visible, 2 - highly visible), crosswalk width, and roadway width (m) were measured at the study locations [16].

\subsection{T-Test}

The $\mathrm{T}$ value is the square root of the ratio between the Mean Square Regression (MSR) and the Mean Square Error or Residual (MSE), or the square root of F (=37.199). With the significance level (a) and degree of freedom (d.f.) being 0.05 and 9 respectively, the critical-t value is 2.262 and the $T$ value for the model is 6.099. Since $\mathrm{T}$ is greater than critical-t, consequently it can be concluded that the correlation is significant and the model can be used to calculate the P-LOS Score [10]. 


\subsection{Comparison}

The comparison between the predicted and observed P-LOS data is presented in Fig. 2. The diagram indicates that the P-LOS model which was developed through this study showed results that are close to the observed values. Thus, it can be used to predict the P-LOS Scores [17].

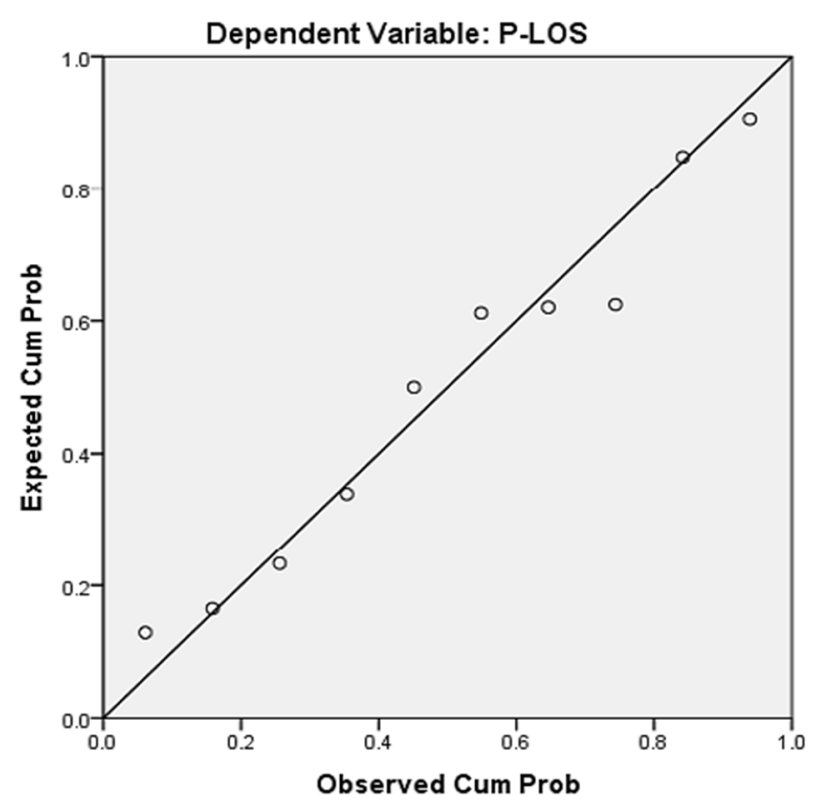

Fig. 2. Normal P-P Plot of Regression Standardized Residua

\subsection{The outcome from the Validation Tests}

Since the P-LOS model which was developed through this study has passed the validation tests (Rsquare value \& T-test), therefore it can be summed up that this model is effective and can be applied to determine the P-LOS Score.

To aid in the determination of the P-LOS of the crosswalk, a LOS table, as shown in the Table. 1 was developed as a basis for stratifying the model's numerical result into a level of service category [17].

Table 1

\section{P-LOS meaning (characteristics) [17]}

\begin{tabular}{|c|c|c|c|}
\hline Pedestrian level of service (P-Los) & P-Los score & Pedestrian level of service (P-Los) & P-Los score \\
\hline A & $8.5<\mathrm{x}<10.0$ & D & $5.0<\mathrm{x}<6.0$ \\
\hline B & $7.0<\mathrm{x}<8.5$ & E & $4.0<\mathrm{x}<5.0$ \\
\hline C & $6.0<\mathrm{x}<7.0$ & $\mathrm{~F}$ & $\mathrm{x}<4.0$ \\
\hline
\end{tabular}

From this study, it was found that the following factors had a greater influence on the level of service of crosswalks at signalized intersections for the study site under consideration:

a) Pedestrian Flow;

b) Pedestrian Crossing Time;

c) Crosswalk Surface Condition.

This study also produced a P-LOS Model that can be applied to analyze the LOS of pedestrian crosswalks at signalized intersections. The model is in the form of the following equation [18]:

$$
P-L O S=7.443-0.002 P F H-0.061 P C T+0.679 C S R,
$$

where $P F H$ - pedestrian flow (ped/hr); $P C T$ - pedestrian crossing time (sec); CSR - crosswalk surface condition rating. $(0-$ poor, $1-$ moderate, 2 - good). 


\subsection{Pedestrian LOS Model}

Stepwise multivariable regression analysis is used to express the mathematical equation for pedestrian LOS. Pools of factors with statistical significance are used from a mathematical expression. This measure evaluates the conditions of crosswalks at intersections. The pedestrian LOS at the crosswalk can be considered in an equation format as shown below [11]:

$$
P-L O S_{\text {crosswalk }}=7.842+\sum_{i=1}^{3} \sum_{j=1}^{3} D_{i j} \cdot \delta_{i j}-(0.037 \cdot p d)-(0.0031 \cdot p b),
$$

where $D_{i j}$ - categorical score associated with j-th level of the i-th attribute; $\delta_{i j}-1$ if the $\mathrm{j}$-th level of the $\mathrm{i}$-th attribute is present; $p d$ - pedestrian delay in seconds; $p b$ - number of pedestrian-bicycle interactions.

\subsection{Significance of P-LOS models}

Using the pedestrian LOS model for a pedestrian crossing, we can analyze the pedestrian crossing in the context of pedestrian safety and comfort.

By applying LOS metrics for pedestrians at a pedestrian crossing, roadway designers can understand the appropriateness of a particular intersection for pedestrian traffic [2].

In other words, the pedestrian LOS methodology analyzes the state of the pedestrian crossing. Using this approach, we will be able to formulate the main priorities of pedestrian needs at operated intersections.

The use of LOS for pedestrians at a pedestrian crossing allows the formulation of a minimum LOS standard to establish the minimum allowable LOS for adequate pedestrian placement. Ensuring a minimum level of adaptation for pedestrians should be one of the challenges in maintaining a minimum LOS for pedestrian crossings at city intersections. facilities.

The application of the LOS methodology is an important tool for the modernization of pedestrian

Based on this model, to implement a high level of service for pedestrian crossings at signalized intersections when planning and designing pedestrian crossings at signal intersections, it is necessary to implement the following [4]:

1. Shorten pedestrian crossing time by reducing crosswalk length and increasing crosswalk width.

2. Increase pedestrian flow by providing a longer pedestrian green time and providing larger walking space.

3. Reduce pedestrian delay by shortening the traffic light cycle length.

4. Improve the condition of crosswalk surface through routine checks and maintenance.

5. Make sure that crosswalk markings at intersections are visible both day and night through routine checks and maintenance.

6. Provide adequate space for holding or accommodating pedestrians while waiting to cross.

7. Provide minimum required roadway width at the intersections to shorten crossing distance and time.

\section{LEADING METHODS OF RESEARCHES}

The HCM 2000 methodology for pedestrian LOS includes criteria for evaluating uninterrupted facilities, shared pedestrian-bicycle facilities, stairs, crossing pedestrian flows, signalized pedestrian facilities, and queuing areas for crossing traffic flows. More specifically, the methodology determines LOS for sidewalks based on the service measure of space and the supplementary criteria of unit flow rate, speed, and volume-capacity $(\mathrm{v} / \mathrm{c})$ ratio [17].

\subsection{Australian Method}

The Australian method of pedestrian LOS depends primarily on three factors, namely the physical characteristics, location factors, and user factors. Pedestrian conditions are described through a LOS grade from LOS A (ideal pedestrian condition) to LOS E (unsuitable pedestrian conditions), based on an assessment of the factors affecting LOS. 
Physical characteristics considered include path width, surface quality, obstructions, crossing opportunities, and support facilities. Location factors address issues related to connectivity, path environment, and the potential for vehicle conflict. The term connectivity refers to the degree to which the path provides a useful, direct, and logical link between attractors and producers of pedestrian trips. Path environment is a measure of the degree of the pleasantness of the surrounding environment and often relates to distance from the roadway. User factors take into consideration pedestrian volume, the mix of path users, and personal security. After these factors have been evaluated, each factor is scored using the criteria and multiplied by their respective weights. Adding these values results in a combined score used to assign the corresponding LOS grades respectively.

The researchers undertook this model after carefully developing it as an iterative process that involved testing and refinement and concluded that it is a good basis for the ongoing measurement of LOS for pedestrians. It also effectively determines which factors contribute to the high or low LOS [17].

\subsection{Trip Quality Method}

This method incorporates the architectural principles of urban design with practical considerations of safety and capacity to form nine criteria for assessment to analyze pedestrian sidewalks for their pleasantness, safety, and functionality. The nine dimensions, taken into account, are enclosure/definition, the complexity of path network, building articulation, the complexity of spaces, transparency, buffer, shade trees, overhangs/awnings/varied rooflines, and physical components/condition.

Each measure is assessed fluctuating from 1 to 5 , with 1 being very poor and 5 being excellent. This method assigns poor ratings to facilities that are not conducive to pedestrians. Taking these factors and the proposed rating system under consideration, the Trip Quality method can be used to calculate an average score for the facility under consideration. The literature did not provide much information about assigning values for each factor, an issue that greatly depends upon the observers' opinions.

One advantage to this method is that rather than creating an aggregate LOS score for the entire road, each measure can be listed separately. This in turn can be used to recommend specific actions to improve a corridor's pedestrian attractiveness [17].

\subsection{Landis Method}

This method is a good attempt to quantify objectively a pedestrians' perception of safety and comfort in the roadside environment. Quantifying the ability to establish how well the roads match foot traffic. This model is developed in the United States through a stepwise multivariable regression analysis of 1.250 observations from an event that put 75 people on a roadway walking course in Pensacola, Florida, and is endorsed by the Florida Department of Transportation.

The Landis Method determines the quality of sidewalk operation taking under consideration the perception of safety and comfort that pedestrian experiences. These factors contribute to a complex assessment of a roadway segment as expressed in the proposed model shown below [8]:

$$
\begin{aligned}
\text { PedLos }= & -1.2021 \ln \left(W_{01}+W_{1}+((f p \%) O S P)+f_{b} W_{b}+f_{S w} W_{S}\right)+ \\
& +0.2531 \ln \left(\frac{V o_{115}}{L}\right)+0.0005 S P D 2+5.3876,
\end{aligned}
$$

where $W_{01}$ - outside lane width (feet); $W_{1}$ - shoulder or bike lane width (feet); $f p$ - on-street parking coefficient $=0.20$; $O S P$ - percent of segment with on-street parking; $f_{b}$ - buffer area barrier coefficient, 5.37 for trees spaced 20 feet on center; $W_{b}$ - buffer width between edge of pavement and sidewalk (feet); $f_{s w}$-sidewalk presence coefficient, $6-0.3 W_{s} ; W_{s}$ - sidewalk width (feet); $V o_{115}$ - average 15 min motor vehicle traffic; $L$ - total number of through lanes for the street; $S P D$ - averaging running speed of vehicles (miles per hour).

It should be noted that the term $W_{01}+W_{1}+f p \% O S P+f_{b} \cdot W_{b}+f_{s w} \cdot W_{s}$ is an expression of the lateral separation. This term refers to barriers, buffers, and the presence of sidewalks and determines the ability of a pedestrian to have a separate, protected place to walk comfortably along the roadway. As the separation 
from the motor vehicle traffic increases, the pedestrian safety and comfort levels increase as well. The presence of on-street parking, a line of trees, or even a roadside ditch between the areas for motorized and non-motorized travel provides additional safety perceptions.

The term including the $V_{115} / L$ portion is the vehicle factor. In this configuration, a 50/50 directional split is assumed. In cases where the split is different, $\left(V o_{115} / L d\right) \cdot \mathrm{D}$ should be used, where $\mathrm{D}$ is the directional factor and $\mathrm{Ld}$ is the total number of directional lanes for the street.

The resulting Model Score is then compared to a chart to determine LOS with LOS A for a score of 1.5 or less and LOS F for a score greater than 5.5 as shown in Table 1. The LOS model equation is created with a statistical significance of 95 percent level. The formula was calibrated and validated extensively in field studies of 24 road segments. Traffic along the segments ranged from average daily traffic (ADT) of 200 to $18.500 \mathrm{ADT}$ with speeds ranging from 25 to $125 \mathrm{kph}$ (15 to $75 \mathrm{mph}$ ). Overall, this method is one of the most extensively studied and written about methods for assessing pedestrian LOS other than the HCM 2000 method.

Also recently, the Landis Method has been expanded to include intersections, instead of sidewalk segments only. That research itself has been modified to give an overall rating to the facility rather than just portions of it [8].

\section{CONCLUSIONS}

The comparison of the various pedestrian sidewalk assessment methods performed in this study shows that the LOS methodology can provide multiple estimates for the same pavement segment. For example, it can be used for sidewalks located in both urban and university environments, restricting the reliance on the implementation of any of the current approaches to assessing pedestrian LOS.

The study clearly shows that there is a variety of quantitative and qualitative factors affecting the quality of pedestrian operations at sidewalks but no existing methodology captures all these factors in sufficient detail. The development of a pedestrian LOS approach that combines more than one method is a desirable research exercise that is expected to improve the assessment quality and lead to results that are more realistic and consistent in the future. It should also be noted that several of these methodologies only apply to sidewalk conditions while others apply to both sidewalk and crosswalk. This inconsistency makes direct comparisons inappropriate and should be addressed in future research.

The analysis also confirms that the HCM 2000 methodology often overestimates sidewalk LOS as it disregards factors related to user preferences and perceptions and the quality of the walking environment. Thus, it is recommended that the HCM 2000 procedures be modified to incorporate both qualitative and quantitative measures and address remaining issues such as the characteristics and needs of various pedestrian user groups, and calibration issues. To improve further the reliability of the Conjoint Analysis results, a user survey can be conducted that would provide useful inputs on user preference under local conditions. Furthermore, it is recommended that a greater number of sidewalks and more disparate sites are considered in future research to allow for the evaluation of the LOS methodologies over a range of conditions.

LOS on the pedestrian crossing and sidewalk model analyzes the performance of a pedestrian crossing in the context of the safety and comfort of the pedestrian crossing. By implementing the principles of LOS for a pedestrian at a pedestrian crossing, roadway designers can determine how well a particular intersection accommodates pedestrian travel. In other words, the LOS methodology for pedestrians makes it easy to analyze the condition of a pedestrian crossing. This analysis will help to understand the basic needs of pedestrians at existing intersections. Using a minimum LOS standard for pedestrians at a crosswalk will help prescribe a minimum LOS for adequate pedestrian accommodation. Pedestrian crossings at city intersections must meet the minimum pedestrian LOS to maintain a minimum level of accessibility for pedestrians. Maintaining, developing, improving pedestrian objects can serve as a toolkit for the Pedestrian LOS model. Roadway designers can use the pedestrian LOS model to analyze alternative intersection patterns by iteratively changing the explanatory variables to find the most efficient pool of 
factors to achieve the desired LOS. The method projected in this revision affords not only the pedestrian LOS at the intersection but also the factors that contribute to a low and a high LOS.

\section{References}

1. Cepolina, E. M., Menichini, F., \& Rojas, P. G. (2017) Pedestrian Level of Service: the Impact of Social Groups on Pedestrian Flow Characteristics Pedestrian Level of Service: the Impact of Social Groups on Pedestrian Flow Characteristics (in English)

2. Smothers, A., Thomas, J., Fang, W., Young, S., Morrissey, E. A., Beaver, M., \& Melnick, H. (2021). Limiting barriers to exercise through the development of a faith-based community walking program. Journal of Interprofessional Education \& Practice, 100428 (in English)

3. Zuniga-Garcia, N., Ross, H. W., \& Machemehl, R. B. (2018). Multimodal Level of Service Methodologies: Evaluation of the Multimodal Performance of Arterial Corridors. Transportation Research Record, 2672(15), 142-154 (in English)

4. Garau, C., \& Pavan, V. M. (2018). Evaluating urban quality: Indicators and assessment tools for smart sustainable cities. Sustainability, 10(3), 575 (in English)

5. Ji, H., Peng, Y., \& Ding, W. (2019). A Quantitative Study of Geometric Characteristics of Urban Space Based on the Correlation with Microclimate. Sustainability, 11(18), 4951 (in English)

6. Reul, J., Grube, T., \& Stolten, D. (2021). Urban transportation at an inflection point: An analysis of potential influencing factors. Transportation Research Part D: Transport and Environment, 92, 102733 (in English)

7. Kadali, B. R., \& Vedagiri, P. (2016). Review of pedestrian level of service: Perspective in developing countries. Transportation Research Record, 2581(1), 37-47 (in English)

8. Landis, B. W., Vattikuti, V. R., Ottenberg, R. M., McLeod, D. S., \& Guttenplan, M. (2001). Modeling the roadside walking environment: pedestrian level of service. Transportation research record, 1773(1), 82-88 (in English)

9. Gallin, N. (2001). Quantifying pedestrian friendliness--guidelines for assessing pedestrian level of service. Road \& Transport Research, 10(1), 47 (in English)

10. Guensler, R., Grossman, A., Frackelton, A., Elango, V., Xu, Y., Toth, C., ... \& Sadana, R. (2015). Automated sidewalk quality and safety assessment system (No. FHWA-GA-15-1216). Georgia. Department of Transportation. Office of Research (in English)

11. Al-Khateeb, G. G. (2020). Highway Planning, Survey, and Design. CRC Press (in English)

12. Banerjee, A., Maurya, A. K., \& Lämmel, G. (2018). A review of pedestrian flow characteristics and level of service over different pedestrian facilities. Collective Dynamics, 3, 1-52 (in English)

13. Naga Raju, S. (2015). Improving the efficiency of energy recovery systems of wheeled vehicles with electric drive. Mester's thesis. Rourkela: National Institute of Technology (in English).

14. Raad, N., \& Burke, M. (2017, November). Pedestrian Levels-of-Service tools: problems of conception, factor identification, measurement and usefulness. In 39th Australasian Transport Research Forum (ATRF 2017), Auckland , 27-29 (in English)

15. Peterson, S. J. (2020). The Transportation Research Board, 1920 -2020: Everyone Interested Is Invited. Washington, DC: The National Academies Press (in English)

16. Maity, G., \& Roy, S. K. (2018). Multiobjective transportation problem using fuzzy decision variable through multi-choice programming. Intelligent Transportation and Planning: Breakthroughs in Research and Practice, IGI Global, 866-882 (in English)

17. Cepolina, E. M., Menichini, F., \& Rojas, P. G. (2018). Level of service of pedestrian facilities: Modelling human comfort perception in the evaluation of pedestrian behaviour patterns. Transportation research part F: traffic psychology and behaviour, 58, 365-381 (in English)

18. Nag, D., Goswami, A. K., Gupta, A., \& Sen, J. (2020). Assessing urban sidewalk networks based on three constructs: a synthesis of pedestrian level of service literature. Transport reviews, 40(2), 204-240 (in English)

19. Hyndman R. and Athanasopoulos G. Forecasting: principles and practice. Retrieved from https:/OTexts.com/fpp2/ (in English)

Received 20.01.2021; Accepted in revised form 26.04.2021. 


\section{АНАЛІЗ РОЗРАХУНКУ РІВНЯ ОБСЛУГОВУВАННЯ ДЛЯ ПІШОХОДІв}

Анотація. Розглянуто декілька методів оцінювання якості роботи пішохідних об 'єктів на основі рівня їх обслуговування. Важлива проблема сьогодні - наскільки пішохідні шляхи відповідають рівню обслуговування. Очінювання иього рівня є найпоширенішим методом визначення якості об'єктів, пов'язаних із пішохіднимм рухом. Місия, де висока ймовірність конфлікту між різними потоками, часто називають перетинами. I навіть більще, на таких перетинах, зокрема зі складними дорожніми умовами та із рухом велосипедистів, автомобілів та інших транспортних засобів, учасники дорожнього руху стикаються зі складними ситуаціями, коли кожен із них повинен бути впевнений у власній безпеці та передбачати подальші дї й рішення інших користувачів. Розглянуто найпоширеніші та загальновизнані методи оцінювання рівня сервісу на пішохідних иляхах, зокрема: метод інструкції про пропускну здатність автомобільних доріг 2000 р., австралійський метод, метод якості поїздки, модель Ландіса та підхід спільного аналізу. Транспортні засоби, затримка сигналів та взаємодія пішоходів $і$ велосипедистів визначені як основні чинники, щэо впливають на рівень сервісу пішоходів на переходах. Аналіз різних методів дає змогу оцінити та ідентифікувати рівень обслуговування та визначити характеристики, які можуть допомогти у вирішенні питань, щуо стосуються комфорту руху пішоходів. В окремих методах розглянутоі принципи руху транспортних засобів та взаємодія їх із пішоходами. Інші методи більшою мірою стосуються дизайну об'єктів пішохідного середовища, ніж фактичного руху пішоходів. Щоб забезпечити повне розуміння методології визначення рівня обслуговування пішохідних об'єктів, потрібно аналізувати та порівнювати розрахункові показники, отримані різними методими.

Ключові слова: пішохід, пішохідні споруди, перехрестя із великою торгівлею, пішохідний тротуар, інструкиія про пропускну здатність дороги. 